\title{
ZIGBEE BASED WATER QUALITY MONITORING SYSTEM USING SOLAR POWER
}

\author{
Smita Suresh Gaulkar ${ }^{1}$, G. R. Gidveer ${ }^{2}$ \\ ${ }^{I}$ ME Appeared, Department of Electronics and Telecommunication, Engineering, Jawaharlal Nehru Engineering \\ College Aurangabad, Maharashtra, India \\ ${ }^{2}$ Associate Professor, Department of Electronics and Telecommunication, Engineering, Jawaharlal Nehru \\ Engineering College Aurangabad, Maharashtra, India
}

\begin{abstract}
Now a days technology is advancing especially wireless sensor network have numerous application in remote sensing and controlling. So by this technology various environmental parameters can be monitored. Idea comes into the mind to monitor the quality of water because water is one of the important factors for living organism. There are various wireless models such as WiFi, Bluetooth, Wi-Max. Here Zigbee is used as wireless sensor network for monitoring the quality of water because, of its low cost, low power consumption and easy to operate. Rapid development in industry and human activities affects the quality of water. Maintaining the good quality of water is a critical problem. But, by using this new wireless technology the task of monitoring become simple. In this system various sensors are used for monitoring the parameters for water samples as quality of water depends upon number of parameters such as $\mathrm{pH}$, turbidity, dissolved oxygen and many more. The main parameters for this system are $\mathrm{pH}$ and turbidity, for that $\mathrm{pH}$ sensor and turbidity sensor are used. This whole system is powered by solar energy.
\end{abstract}

Keywords: $p H$ Sensor, Turbidity Sensor, Zigbee

\section{INTRODUCTION}

The rapid growth of industry and human activities in $21^{\text {st }}$ century affects the quality of various environmental resources such as air, water. So, living organism does not get safe water for drinking and other domestic uses. As water is important for all living organism the quality of water is very important. Keeping our water resources always within a standard for domestic use, industrial use or for agriculture purpose is very critical problem. Traditionally, there are various technologies, measures and control the quality of water those are based on wired technology but, when it comes to the particular area it is hard to implement and does not give required results. So, other technology must be developed, for rapid development. In wireless technology it gives required results so; it is advantageous to monitor the quality of water.

The idea comes into the mind to develop such system which can monitor the quality of water by measuring various parameters for water sample from different places such as dam, river, and well. As the quality of water depends upon various parameters such as $\mathrm{pH}$, turbidity and dissolved oxygen and many more. The use of wireless technology for monitoring purpose will not only reduce the installation cost but also reduces the man power and provide flexibility in terms of distance and also provide real time data. In this system $\mathrm{pH}$, turbidity is the parameters of interest, for that system consist of $\mathrm{pH}$ sensor and turbidity sensor for measuring the value of $\mathrm{pH}$ and turbidity respectively.

The values of these parameters are calculated in real time which is then transmitted to base station via Zigbee wireless model. As it is popular and widely used wireless technology having low power consumption with high power transmission. Zigbee uses IEEE 802.15.4 standard for its reliable communication. All sensors are placed at remote site and values which are measured by sensors are then transmitted to base station for analysis purpose. Base station contains computer and Zigbee receiver. Received values are displayed on computer for analysis. Power supply has become important issue regarding use of wires to connect various nodes to power line is not practical way because sensors are placed in water bodies. Another method is the use of battery which has advantage, as it is portable but has limited lifespan and cannot use for long period. Replacement of battery is also inconvenient to avoid these problems this whole system is powered by solar energy which helps to keep pollution free environment.

\section{RELATED WORK}

As wireless technology have huge applications in monitoring various environmental parameters such as water monitoring, greenhouse monitoring, agriculture monitoring and many more. One of the important monitoring considered here, is water quality monitoring [1].

Some of the work on similar topic has been done previously but most of them were wired system, although some of them were wireless system but they were costly or large in size. Design of water quality measurement sensor by using robot was one of the systems which were reliable and less power consuming but the system was costly and complicated for installation [2]. 
In some cases the system was developed for measuring only single parameter either $\mathrm{pH}$ or temperature or conductivity which was not feasible to developed system for measuring only single parameter [3].

The system was implemented for water quality monitoring made up of various wireless sensors and unmanned autonomous vehicles controlled by central monitoring station. The challenging task was selection of sensors and choosing subset of sensors because these sensors were battery operated, battery has limited capacity and transmission-reception of data was energy consuming action. Another challenge was control of unmanned autonomous vehicles (UAVs) because, wireless link can suffer data loss over long distance, delay can be occurred which degrade the performance of the system [4].

System which was designed for under water monitoring and controlling uses GPRS modem for monitoring data. The parameters from water bodies like $\mathrm{pH}$, temp was calculated by motes which were powered by batteries, the main challenge was to provide reliable data transfer because underwater sensor network were having limited bandwidth as properties of underwater channels differ from ground based and system was battery operated so has limited lifespan [5].

The system was developed for monitoring industrial sewage in which different sensors were used. Which were used to measure the parameter values from water body they were connected to base station via GSM network but, problem may cause when, GSM network is not in coverage [6].

So, idea comes into mind that a system should be implemented. That, it can monitor quality of water in easy way and critical factors of water can be easily analyzed. The system uses $\mathrm{pH}$ sensor, turbidity sensor for monitoring the $\mathrm{pH}$ and turbidity parameters from water samples. Rapid development in wireless technology provides novel approach to real time data transmission and processing. Zigbee model has been used as data trans-receiver. As system is located at remote place, powering to the system is an important task, Here solar panels are used which is advantageous and environment friendly.

\section{SYSTEM MODEL}

\subsection{Overview}

This section represents overview of system and introduces the functionality of each component. Recent improvements in communication mainly, in wireless technology have numerous applications in sensor network. In this system the main aim is to monitor the quality of water by using different sensors and data is transmitted via Zigbee wireless model. As water plays important role for living organism the quality of water must be up to the required standard, so the system is developed by using ATMEGA328, $\mathrm{pH}$ sensor, turbidity sensor and Zigbee trans receiver.

\subsection{Location Site}

Figure 1 depicts the block diagram at location site. It is having -

A) Sensor Unit: It is having various sensors like $\mathrm{pH}$ sensor, turbidity sensor for measuring $\mathrm{pH}$, turbidity parameters for water sample.

$\mathrm{pH}$ Sensor: The term $\mathrm{pH}$ refers Positive Hydrogen. The balance of Positive Hydrogen ions $(\mathrm{H}+)$ and negative Hydroxide ions $(\mathrm{OH}+)$ in water determines how does it acidic or base? This sensor is used to measure the value of $\mathrm{pH}$. The scaled range of $\mathrm{pH}$ is from 0 to $14, \mathrm{pH}$ value 7 refers to neutral $\mathrm{pH}$ (Pure water). The value below 7 refers to acidic water and above 7 refers to alkaline water.

Turbidity Sensor: Turbidity measures how cloudy water is? For best quality drinking water turbidity has to be within 0 to 5 NTU.

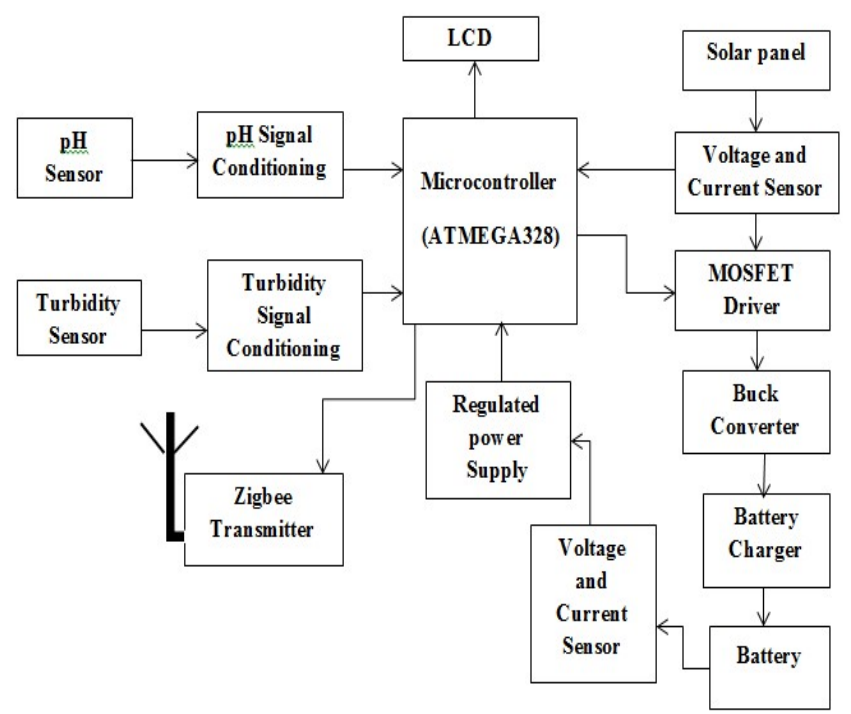

Figure 1: Block Diagram of Wireless Sensor Network at Location Site

B) Microcontroller: Here ATMEGA328 microcontroller IC is used which is having 28 pins and its clock frequency is $20 \mathrm{MHz}$. All the sensors and Zigbee model are connected to the microcontroller. It has the advantages of operating at high clock frequency up to $20 \mathrm{MHz}$, low power consumption; supply voltage can be $1.8-5.5$ volts.

C) Zigbee Model: It is wireless Trans-receive model for transmission and reception of data. It is going to operate on IEEE 802.15.4 standard. This can be operated on carrier frequencies of 2.4-2.48 GHz, 902-928 MHz, 868-868.6 $\mathrm{MHz}$. It is operated on 3.3 Volts supply and range of communication is from 30 meters to 100 meters.

D) Solar Panel: Powering the system is main issue when system is operated at remote site. Availability of mains power supply at such site is very difficult. The system is required to be operated on batteries (chargeable). Such batteries can be charged either on main supply or using solar panels. This system is operated on 12 Volt battery supply. 


\subsection{Base Station Site}

Figure 2 shows the block diagram of base station site. It is having Zigbee receiver to receive the data collected from the location site which is then sent to computer via USB to serial cable.

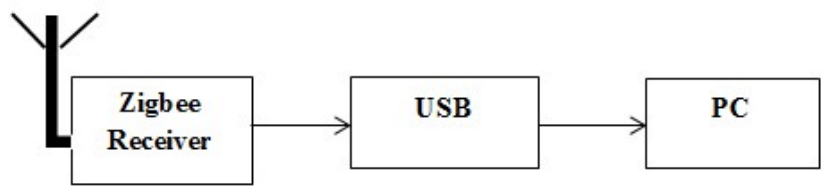

Figure 2: Block Diagram of Wireless Sensor Network at Base Station

\section{RESULTS}

Initially the laboratory experiments are carried out to determine the $\mathrm{pH}$ and turbidity values of different water samples. Then the sensors of this system are calibrated accordingly. The whole system is tested repeatedly to read the $\mathrm{pH}$ and turbidity values of same samples, it is found that all readings are in very close limits. The average value of some samples is listed in the table given below.

Table- 1: Reading of $\mathrm{pH}$ value

\begin{tabular}{|l|l|l|l|l|}
\hline $\begin{array}{l}\text { Sr. } \\
\text { No. }\end{array}$ & $\begin{array}{l}\text { Name of } \\
\text { Sample }\end{array}$ & $\begin{array}{l}\text { Reading of } \\
\text { Standard } \\
\text { System (a) }\end{array}$ & $\begin{array}{l}\text { Reading } \\
\text { of this } \\
\text { System } \\
\text { (b) }\end{array}$ & $\begin{array}{l}\text { \% Error } \\
{[(\mathrm{a}-\mathrm{b})} \\
\mathrm{a}]^{*} 100\end{array}$ \\
\hline 1 & $\begin{array}{l}\text { Corporation } \\
\text { Water }\end{array}$ & 8.0 & 8.3 & -3.75 \\
\hline 2 & Pound Water & 7.9 & 7.6 & 3.79 \\
\hline 3 & Well water & 7.7 & 8 & -3.89 \\
\hline 4 & Harsul Area & 7.7 & 7.4 & 3.89 \\
\hline
\end{tabular}

Table- 2: Reading of Turbidity value

\begin{tabular}{|l|l|l|l|l|}
\hline $\begin{array}{l}\text { Sr. } \\
\text { No. }\end{array}$ & $\begin{array}{l}\text { Name of } \\
\text { Sample }\end{array}$ & $\begin{array}{l}\text { Reading of } \\
\text { Standard } \\
\text { System (a) }\end{array}$ & $\begin{array}{l}\text { Reading } \\
\text { of this } \\
\text { System } \\
\text { (b) }\end{array}$ & $\begin{array}{l}\text { \% Error } \\
{[(\mathrm{a}-\mathrm{b})} \\
\mathrm{a}]^{*} 100\end{array}$ \\
\hline 1 & $\begin{array}{l}\text { Corporation } \\
\text { Water }\end{array}$ & 0 & 0 & 0 \\
\hline 2 & Pound Water & 229 & 241 & -5.24 \\
\hline 3 & Well water & 0 & 0 & 0 \\
\hline 4 & Harsul Area & 222 & 230 & -3.60 \\
\hline
\end{tabular}

\section{CONCLUSIONS}

The system is wireless. It can be installed at any remote site. The Zigbee model will communicate the values of these parameters at our required place.

After determining the values their usability and application is decided.

For the purpose of drinking water the recommended value of $\mathrm{pH}$ is 6 to 8 and turbidity within 0 to 5 NTU.

Such systems are very much useful in monitoring and control of pollution.

As it is powered by solar energy it can be used at any remote places and saves the cost of energy.

\section{ACKNOWLEDGEMENT}

The authors gratefully thank the Jawaharlal Nehru Engineering College Aurangabad, Maharashtra State for providing the platform for intended work. Also, thankful to our friends and family members to their constant support.

\section{REFERENCES}

[1]. Mohd Fauzi Othman, khairunnisa Shazali "Wireless Sensor Network Applications: A Study in Environment Monitoring System" International Symposium on Robotics and Intelligent Sensors 2012 (IR IS 2012) pp1204-1210

[2]. JA Hyo Ku,Hun Jung and Jon Ho Park "Design of Water Quality Measurement Sensor Robot based on Wireless Communication Environment "International Journal of Smart Home vol.7, No.4,July 2013 pp107116

[3]. G. Sharma, N. Pradhan, B. Chettri, D. Bhattacharjee "Development of Wireless pH measuring Device" International Journal of Advanced Research in Electrical, Electronics and Instrumentation Engineering ( An ISO 3297:2007 Certified Organization ) Vol.3, Issue 4, April 2014 pp8629-8635

[4]. Li Zhenan, Wang kai, Liu Bo "Sensor Network based Intelligent water Quality Monitoring and Control " International Journal of Advanced Research in Computer Engineering and Technology(IJARCET) vol.4, Issue 2, April 2013 pp1459-1462

[5]. Mustafa Shakir, Mohmood Ashraf Khan, Shahazd A. Malik and Izhar-Ul-Haq " Design of Underwater Sensor Network for Water Quality Monitoring" World Applied Science Journal 17(11): 1441-1444 2012

[6]. Akila.U. Elackiaselvi.R, Maheshwari.R, Shunmugavalli.K, T.Prathiba "Industrial Sewage Water Quality Monitoring System" International Journal of Engineering Research and General Science Vol.3, Issue 2, March-April 2015 ISSN 2091-2730 pp1285-1292

\section{BIOGRAPHIES}

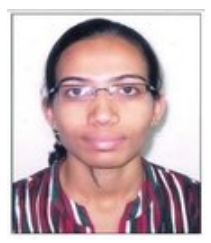

Smita Suresh Gaulkar - She has completed the B.E. degree with Distinction from the Department of Electronics and Telecommunication Engineering, from Jawaharlal Nehru Engineering College, Aurangabad in 2013. Currently pursuing Masters in Electronics from same institute.

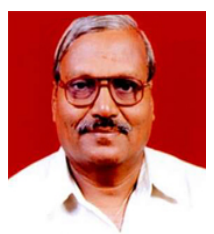

Prof. G. R. Gidveer - He is currently working as Associate Professor Department of Electronics and Telecommunication at Jawaharlal Nehru Engineering College. His total teaching experience in years is 40 years. He has guided more than 20 candidates at Master level projects. He is also acted as consultant for Dept. of Police and Municipal Corporation Aurangabad. 